\title{
UNION WITH CHRIST: THE EXISTENTIAL NERVE OF PURITAN PIETY
}

\author{
by $R$. Tudur Jones
}

\section{Introduction}

J.C. Brauer of Chicago has complained recently that so little scholarly attention has been paid to the nature of Puritan piety. He finds most students of Puritanism reprehensible in this matter, not excluding such distinguished names as Perry Miller, William Haller and M.M. Knappen. ${ }^{1}$ There is a similar scarcity in New Testament scholarship. A.J.M. Wedderburn has also noted that so few monographs have been published on the Pauline formula 'in Christ'. ${ }^{2}$ It may well be that in our activist age concentration on piety may be considered a retreat from public responsibility. All the more reason then why it might be worthwhile to examine what the Puritans had to say about union with Christ, especially since so many of the men who wrote about it were even more activist than most of our contemporaries.

\section{An Old Tradition}

Union with Christ has been a prominent element in Christian experience and thinking throughout the centuries. That is especially true of Mystical Theology. But it is also true of Protestantism. When extolling the blessings of faith, Luther wrote "The third incomparable benefit of faith is this, that it unites the soul with Christ as a bride is united with her bridegroom. And by this mystery... Christ and the soul become one flesh. ${ }^{3}$ Calvin similarly insists that there can be no benefit to us unless the Holy Spirit engrafts us into Christ. "To this is to be referred that sacred marriage, by which we become bone of his bone, and flesh of his flesh, and so one with him' (Eph.

\footnotetext{
1'Types of Puritan Piety', Church History 56 (1987) 39.

'Some observations on Paul's Use of the phrases "In Christ" and "With Christ"', JSNT 25 (1985) 83.

${ }^{3}$ Treatise on Christian Liberty (1520) in Works (Philadelphia Edition) II, 320.
} 
5:30). ${ }^{4}$ As Peter Toon has rightly emphasised, union with Christ was of 'supreme importance to Calvin' ${ }^{5}$ This conviction was woven into the fabric of Protestant thinking here in Britain in the sixteenth century. It is not confined, of course, to the Puritan movement. It is proposed to concentrate on what those Puritans had to say about it in England and Wales.

\section{Significance of the Theme}

At the beginning of the period, we find union with Christ being discussed in the work of William Perkins, fellow of Christ's College, Cambridge, up to 1595 and after that lecturer at Great St. Andrew's, Cambridge. In his tract, A Grain of Mustard Seed, he wrote that 'a sinner in the very first act of his conversion is justified, adopted and incorporated into the body of Christ. ${ }^{6}$ And at the end of our period, John Bunyan (1628-88) in his Grace Abounding, describes his release from guilt in the words, Now did my chains fall off my legs, indeed, I was loosed from my affliction and irons, my temptations also fled away'. Then he added, 'Further, the Lord did also lead me into the mystery of union with this Son of God, that I was joined to him, that I was flesh of his flesh, and bone of his bone. . .7 And in between these two writers a host of other authors expounded their views on the theme.

As we proceed with the analysis, the fundamental importance of this experience will become increasingly obvious. The presupposition of communion with God and with other Christians is union with Christ. 'Union. This is the basis of communion', said David Clarkson (1622-86). ${ }^{8}$ And Walter Cradock strikes the same note when he says that 'there can be

\footnotetext{
${ }^{4}$ The Institutes of Religion, III. 1.3.

${ }^{5}$ Hyper-Calvinism (1967) 128, following F. Wendel, Calvin, 232.

${ }^{6}$ Works (1616) I, 637.

${ }^{7}$ Both Perkins and Bunyan are included as examples of conversion by F.W.B. Bullock, Eoangelical Conversion in Great Britain 1516-1695 (1966) 32, 73, but in his analysis of the experience he makes no mention of union with Christ, 91112.

${ }^{8}$ Works (1864) III, 166, Clarkson was Fellow of Clare Hall, Cambridge, 1645-51; Rector of Mortlake, Surrey, until ejected in 1661; assistant to Dr John Owen at Leadenhall Street, London, and 1683, his successor, Biography in Works I; v., also A.G. Matthews, Calamy Reoised (1934) hereafter cited CR.
} 
no communion where there is no union'.9 This communion, according to Matthew Barker,

consisteth of the Divine Operations of our Souls towards God, when the faculties of the Soul are tending towards him, and terminated upon him; when the Mind is exercised in the contemplation of him, the Will in chusing and embracing him, when the Affections are fixt upon him, and center in him, when by our Desires we pursue after him, by our Love we cleave to him, and by Delight we acquiesce and solace ourselves in him. ${ }^{10}$

In other words, there is no part of the believer's human personality that is not affected by the beneficial consequences of union with Christ. The theme that engages our attention is therefore one of central importance.

\section{The Order of Salvation}

To be in Christ, said John Preston (1587-1628), is the ground of all salvation'. ${ }^{11}$ It lies at the commencement of our spiritual renewal. Richard Baxter (1615-91) agreed with Preston. The 'first and great work of faith is to receive and close with the person of Christ'. 'He is the vine, and we are the branches; we must be planted into him, and live in him, or else we can have nothing further from God'.12 This is a point reiterated by a very large number of Puritan theologians and their consensus, not surprisingly, is echoed in the Westminster Standards. The Westminster Assembly's Larger Catechism asserts that union with Christ impinges upon the believer's experience in effectual calling. The Union then leads to Communion in Grace and that is defined as the believers' 'partaking of the virtue of [Christ's] Mediation, in their Justification, Sanctification, and

\footnotetext{
${ }^{9}$ The Saints Fulnessse of Joy in their Communion with God. . . (1646). For Cradock (1610?-59) v., Dictionary of Welsh Biography; DNB, Geoffrey F. Nuttall, The Welsh Saints (1957) 18-36.

${ }^{10}$ A Continuation of Morning-Exercise (1683) Sermon xix, 1022. For Barker (died 1698) M.A. of Trinity, Cambridge, 1641; prominent London Independent minister, 0., DNB, CR.

${ }^{11}$ An Abridgement. . . (1648) 738. For Preston (1587-1628) of King's and Queen's Colleges, Cambridge, and leading preacher at Cambridge and Lincoln's Inn, 0. , DNB.

${ }_{12}$ Directions and Persuasions to a Sound Conversion in Works (ed.. W. Orme, 1830), VIII, 138, For Baxter (1615-91), 0., Geoffrey F. Nuttall, Richard Baxter (1965); DNB, CR.
} 
whatever else in this life manifests their Union with him'. ${ }^{13}$ It is then an integral stage in the Order of Salvation and a most significant precursor of what follows. It is therefore all the more surprising that while Justification and Sanctification have had their share of theological consideration there has been a deep and prolonged silence about union with Christ. But the Puritans were not silent about it.

Thomas Cole, in his book $A$ Discourse of Regeneration (1689), asserted that the basis of a believer's union with Christ lies in the Incarnation when he wrote, "The Humane Nature of Christ is the foundation of all our Communion with God: our access to God is through the veil of his flesh' ${ }^{14}$ Or in more academic language, "The Hypostatical Union of the Divine and Humane Nature in the Person of Christ, was in order to the Spiritual Union of our Persons to the Person of Christ' ${ }^{15}$

John Bunyan agreed when he said that the indwelling of God in the believer 'begins first in its Eminency, by his Possessing our Flesh in the Person of Jesus Christ'. ${ }^{16}$ Edward Reynolds sees the union of the two natures in our Lord as the pattern of the Church's relationship to Christ. In 'the Hypostatical Union there is an inseparable conjunction of the manhood to the Godhead in one person', so in the 'mystical union, there is an inseparable conjunction of the members to the head in one Church or body'. ${ }^{17}$ Isaac Ambrose makes a rather more individualistic point. In the hypostatical union 'it pleased God to assume and unite our human nature to the deity', so in

${ }^{13}$ The Confession of Faith, Together with the Larger and Lesser Catechisms. . .Composed by the Reverend Assembly of Divines. . ( (London 16582) 89-91.

${ }^{14} A$ Discourse of Regeneration (1969) 137, For Cole (1627?-97), Principal of St Mary's Hall, Oxford 1656-60, $v$., DNB, CR.

15 Ibid., 88.

${ }^{16}$ Light for them that sit in Darkness (1675) in Richard L. Greaves, John Bunyan: Miscellaneous Works, VIII (Oxford 1979) 84.

${ }^{17}$ Joy in the Lord: Opened in a Sermon Preached at Pauls, May 6 (London 1655) 9, For Reynolds (1599-1676), of Merton College, Oxford, member of the Westminster Assembly, Vicar of St Lawrence, Jewry, 1645-62; Dean of Christ Church, 1648-50; conformed at Restoration; bishop of Norwich, 1661-1676, v., DNB and James Reid, Memoirs of the Westminster Divines, II, 128-131 (reprinted by Banner of Truth Trust, 1982). 
the spiritual union of Christians with Jesus Christ it pleased God to unite the person of every believer to the Son of God'. ${ }^{18}$

The Westminster Assembly's Larger Catechism describes the union of the elect with Christ as the work of God's grace, 'which is done in their effectual Calling'. So union with Christ is contemporaneous with effectual calling and precedes Justification, Adoption and Sanctification. John Flavel, when he wrote his Exposition of the Assembly's Catechism, put the point succinctly when he wrote of this union, It makes Christ, and all that he hath purchased, become ours'. ${ }^{19}$ The Holy Spirit, he believed, applies redemption by 'working faith in us, and thereby uniting us to Christ in our effectual calling. ${ }^{20}$

Thomas Goodwin sought to analyse the progress of this union. Firstly, We are one with Christ before the world was"'. Secondly, in his incarnation Christ was united to us in another way; 'he represents us, doth what we have to do'. But a third form of union is needed to apply the work of redemption and that involves Christ's undertaking to 'take the soul, to work in it all that he as a common person hath wrought for ${ }^{2} t^{\prime}{ }^{21}$ In other words, 'A man, before he is called, is justified in Christ, but not with Christ; that is, it is not actually applied to the man's person'. 22 So Goodwin introduces a further refinement into the teaching of the Westminster standards by positing a form of justification which precedes effectual calling. These are very fine distinctions and some of Goodwin's contemporaries were uneasy about them because they come uncomfortably close to the teaching of the hyper-Calvinists that the elect have been justified from eternity. But Goodwin himself rejected the criticism. ${ }^{23}$

\footnotetext{
${ }^{18}$ Looking unto Jesus in Works (n.d.) 215, For Ambrose (1604-64), Presbyterian vicar of Garstang, Lancashire, ejected 1662, 0., CR.

${ }^{19}$ The Whole Works of the Reo. Mr John Flavel VI (London 1820) 192-3. For Flavel (died 1691) Lecturer at St Saviour's, Dartmouth, and Townstall, Devon, ejected $1662,0 ., C R$.

20 Ibid., 191.

${ }^{21}$ Ephesians in Works II, 242. For Goodwin (1600-80) 0., DNB, CR. A memoir by Robert Halley and one by Goodwin's son, (which contains his autobiography), is prefaced to Works, II. He was President of Magdalen College, Oxford 1650 60 , and one of the leaders of Congregationalism after the Restoration.

22Ibid., 246.

${ }^{23}$ Ibid., 242.
} 
Thomas Cole does not deny the eternal dimension in salvation. Regeneration, he writes, begins in 'the Eternal Purpose of God in Election' but it is an eternal purpose, not an actuality and that purpose, in order to be fulfilled, proceeds 'downwards through all the methods, ways, and means appointed by God for the carrying on this great work of his in the hearts of men.'24 Actual regeneration, he argues, consists in the soul's 'ingrafture into Christ by a vital Union to him through faith'.25 So faith, Union with Christ and regeneration are contemporaneous. ${ }^{26}$ And all this is the work of the Holy Spirit. ${ }^{27}$ John Owen similarly insists that no sinner 'who hath not been made a partaker of the washing of regeneration, and the renovation of the Holy Ghost, can possibly have any union with Christ', not that the renovation precedes the union but both are 'immediately and inseparably' bound together. ${ }^{28}$

A point of considerable significance emerges here. Ever since Gregory of Nyssa (330-c. 395 AD), the so-called 'Father of Christian Mystical Theology', had distinguished three stages in the spiritual pilgrimage, those of purification, enlightenment and (after darkness), union with God, this scheme had become a standard pattern. Bonaventure (whom Pope Leo XIII called the 'Prince of Mystics'), elaborated upon it in his Threefold Way. For him the culmination of spiritual experience is 'the way of Union, and in that the Bridegroom is received'. Recently in his perceptive study of Puritan spirituality, Puritan Devotion, Gordon S. Wakefield pointed to the contrast between the Roman Catholic understanding of the spiritual pilgrimage and that of the Puritans. For the Puritan, he said,

\footnotetext{
${ }^{24} A$ Discourse of Regeneration, 38.

${ }^{25}$ Ibid., 81.

${ }^{26}$ Ibid., 83.

27 Ibid., 85.

${ }^{28} A$ Discourse concerning the Holy Spirit in ed. W.H. Goold, Works (Banner of Truth 1977) III, 464. George Swinnock identified Union with Christ with regeneration and they precede justification, The Door of Salvation Opened. . . (1659) in Works (Edinburgh, 1868) V, 40. Swinnock (died 1673), was ejected from Great Kimble, Bucks. 1662, 0., CR. The same stand-point is taken by Samuel Bolton (1606-54), The Dead Saint Speaking. . . (1657) 61. For Bolton (1606-54), Master of Christ's College, Cambridge, 0., B. Brook, The Lives of the Puritans III (1813) 223-4. That Union with Christ precedes Justification is stated by Thomas Goodwin in Works VIII, 406, and by Isaac Ambrose in Media: The Middle Things (London $\left.1657^{3}\right) 3$.
} 
'Union with Christ is not the end but the beginning of the Christian life'. He added that it is not inappropriate to say that the Puritans also thought of three ways, but for them they were Justification, Sanctification and Glorification. ${ }^{29}$ Gordon Wakefield's analysis is fully justified. One significant implication of this is that union with Christ is not to be understood as the achievement of a few heroic souls but a divine gift received by all true Christians. There would be no Christian life at all, so the Puritans argued, without such union. If it be asked whether the two patterns can be reconciled, it can only be admitted that that would be a formidable task. Indeed, it may be impossible of fulfilment.

\section{General Nature of the Union}

Puritan writers often indulge in general descriptions of Union with Christ. John Flavel (died 1691) can provide us with a full and eloquent example. First he defines the Union negatively. It is not a 'meer mental union', nor is it a 'Conceit or Notion'. It is not a physical union, nor is it 'an essential union, a Union with the divine Nature'. Neither is it a 'Union by covenant only', nor a 'meer moral Union by Love and Affection'. What then is it positively? Flavel lists ten of its characteristics and they may be summarized as follows. It is a union which 'knits our Persons most intimately and nearly to the Person of Christ'. It is 'wholly supernatural', the product of God's power. It is an 'immediate Union', in the sense that all 'Members of Christ's mystical Body' are equally close to the Redeemer. It is a 'fundamental Union' because all our spiritual well-being springs from it. It is 'efficacious', 'indissoluble' and 'honourable'. It brings comfort, is fruitful and 'enriching' because it gives access to all Christ's riches. ${ }^{30}$ It is well to note the Christological concentration which characterizes the analysis. Our relation with God is always through the Mediator, Jesus Christ. And our Union with Christ is rendered possible at all because the Divine Logos assumed our flesh albeit without sin.

${ }^{29}$ Puritan Devotion (1957) 160.

${ }^{30}$ Sermon 2 on John 17:23 in The Works of John Flavel (2 vols. 1701) I. 245. 
It is the humanity of the God-man that provides the ontological bridge between us and the divine nature.

It is as well to draw attention here to one of Flavel's negative points. The Union. he said, is not 'an essential union, a Union with the divine Nature'. The mainline Puritans were extremely anxious to emphasise that union with Christ did not mean merging the human and the divine. One unnamed preacher-I take him to be Samuel Annesley, John Wesley's Presbyterian grandfather-insists that believers and God 'are not essentially one as the Father and Son are one', that is, they do not share the same essence. Nor are they 'one personally, as the Divine and Human Nature of Christ', which form one person. ${ }^{31}$ Matthew Barker was equally emphatic when he urges us to 'think soberly' of communion with God: 'It is not a transformation of the Soul of Man, into the Divine Essence, and Being, as if Man was made God, swallowed up into him, and lost his own Existence and Being in God. . . 32 It is true, as we shall see, that there were more radical Puritans who did not share this diffidence. But the denial of an essential union by the main body of Puritans is of relevance when considering the question of Puritan mysticism.

When discussing the nature of union with Christ, the Puritans were, as always, seeking to do justice to the evidence of Scripture. They searched for suitable comparisons and metaphors that would enable them to describe the experience. John Flavel, for example, elaborates on 'four elegant and lively Metaphors' that Scripture uses to help us understand the nature of the 'mystical union with Christ'

Pieces of timber, united by Glue; that of a Graff taking hold of its stock and making one tree; that of the Husband and Wife; becoming one flesh; and that of the Members and Head animated by one Soul, so becoming one natural Body. ${ }^{33}$

\footnotetext{
${ }^{31}$ Sermon 27 in A Continuation of Morning-Exercise. . (1683) 969. The editor of the volume was Annesley. The name of the preacher of each sermon is given in the list of contents, opposite the subject of his sermon. But the author of sermon 27 is unnamed and may well be the editor himself. For Annesley (1620-96), ejected from St. Giles, Cripplegate, in 1662, o., DNB, CR.

32Ibid., Sermon 19 on 1 John 1:7.

${ }^{33}$ Works of John Flavel (1701) I, Sermon 2 on John 17:23.
} 
The first is a reference to Ezekiel 37:1519-God taking the stick of Israel and the stick of Judah and making them one. Walter Cradock too liked this metaphor,

... there is a great union between two boards glewed together; for I have heard Joyners say, it is sometimes stronger than the board itself, as a broken bone is stronger when it is knit, then before ever it was broken. ${ }^{34}$

The metaphor of grafting comes from Romans 11:17-24; that of the husband and wife from Ephesians 5:21-30; that of Head and members from I Corinthians 12:12-27. But these are by no means the only metaphors and analogies that were quoted. Some Scripture passages and concepts played a very substantial role in expositions of the theme of union with Christ and we can now examine those.

\section{The Covenant}

Union with Christ can be considered as a covenantal relationship. Many of the Puritans subscribed to some form or other of the Federal Theology. If union with Christ is of the essence of salvation, the human tragedy of sin could be understood as union with Adam, whose breach of the Covenant of Works brought the divine curse on humanity. Stephen Charnock went a step further and held that since the human race is genetically in Adam, 'we are united to the Devil, as the Head of the wicked world. We are by nature his Members' ${ }^{35}$ But grace is at work to divorce the elect from the Devil. By the Covenant of Grace believers are united to Christ. There were variations in the ways in which theologians conceived of the details of Covenant Theology and the parties implicated in them. Whereas most theologians were content to speak of two covenants, some posited three. Charnock is an example of one who took this view. He distinguished between a Covenant of Grace and a Covenant of Redemption. In the Covenant of Redemption,

\footnotetext{
${ }^{34}$ Divine Drops Distilled (1650) 71.

${ }^{35}$ Discourse of the Necessity of Regeneration in The Works of. . Stephen Charnock II (London,1684) 31. For Charnock (died 1680) of Emmanuel College, Cambridge; Fellow of New College, Oxford 1650; Presbyterian pastor at Crosby Hall, Bishopsgate, after the Restoration, $0 ., C R$.
} 
the parties are the Father and the Son. ${ }^{36}$ This had to do with the way in which the Son of God would become incarnate and make atonement for sin and so make salvation possible. And believers would become his people in virtue of his fulfilling the agreement. So 'all the seed of Christ are in the covenant of redemption before they are regenerate' ${ }^{37}$ But our participation in the benefits of that covenant is to be understood in the light of the Covenant of Grace, the parties to which are God and man. Although this Covenant, like the Covenant of Redemption, was decided upon in eternity, its implementation takes place in time. 'Faith is the condition of the Covenant of Grace; death required on Christ's part, faith required on man's part' ${ }^{38}$ It follows that believers are not in the Covenant of Grace until they are regenerate. ${ }^{39}$ This elaboration of the theology of the covenants by Charnock exemplifies the tendency to move beyond the testimony of Scripture into the realm of scholasticism. It illustrates why some students of the period see the Federal Theology as the intrusion of rationalism into Puritan thought.

Federal theology did give both Adam and Jesus Christ a unique status. This was the status of common or public persons. It is a unique status because, as Jeremiah Burroughs put it, 'there were but two men ever in the world [that] were public persons' ${ }^{40}$ Only by giving Adam this status could the universality of sin be explained. And only by giving Jesus Christ this status could believers' union with him be understood. So Burroughs can extol the Saviour by saying, 'Christ is wonderful in his sufferings, because he suffered as a common Person, he did not suffer as a particular man'. And it was, he adds, because He agreed in the Covenant of Grace to become 'a publicke person'.41

Similarly for Thomas Goodwin the concept of Christ as 'a person representative' makes it possible to understand how

${ }^{36}$ Works, III, 375.

${ }^{37}$ Ibid., 378.

${ }^{38}$ Ibid., 374.

${ }^{39}$ Ibid., 376.

${ }^{40}$ Gospel-Revelation, 133-4.

${ }^{41}$ The Saints Happinesse (1660) 242-3. For Burroughs (1599-1646), rector of Tivetshall, Norfolk, 1631; suspended 1636; teacher to the English congregation at Rotterdam, 1637-41; preacher at Stepney, 1641; member of the Westminster Assembly, v., DNB. 
our spiritual renewal is dependent upon the fact that Christ's saving work implicates us all. Insomuch as Christ was raised from the dead and quickened, so 'we are said to be raised and quickened in him'. 'Our life is bound up in the bundle of the life of our Lord and Saviour Jesus Christ'. ${ }^{42}$

These words by Thomas Goodwin, who was a notably warm-hearted theologian, are a reminder that there is more to the Covenant Theology than an intellectual scheme for reconciling divine mercy with the demands of divine justice. It has been fashionable of late to dwell on the mercantile and legalistic elements in the Federal Theology, as for example in David Zaret's study, The Heavenly Contract (1985). It is perfectly permissible, of course, for historians to examine the impact of covenantal thinking on social and political life. It was, after all, a type of thinking that could be easily secularised and transformed into such concepts as a social contract. But we are bound to listen carefully to what the Puritans did say about the Covenant of Grace and to note that Union with Christ was for them an integral part of it and that that inspired a warm and highly personal piety centred on Jesus Christ.

William Bridge may be quoted as an example. ${ }^{43}$ On the one hand he can use a legal metaphor. For the Christian, he says, the Covenant is the Magna-charta of all his spiritual Privilidges'. That is its objective significance. But what he says immediately afterwards reveals the emotional and pastoral consequences of the Covenant. Those who are dispirited and feel that they are weak in grace should realise that the Covenant is a proclamation by God to his people that 'He wil not cast them off, but he wil rather be moved to pity them'. Even more significant is what comes next. The federal relationship between God and his people is like a marriage covenant which declares, 'I wil betroth thee unto me for ever [Hos.2] saith the Lord.44 To be in the Covenant of Grace is to be, he says, in a 'Conjugal and Paternal' relationship. When

\footnotetext{
${ }^{42}$ Ephesians in Works, II, 211.

${ }^{43}$ For Bridge, Town Preacher at Yarmouth when ejected in 1661, v., C.R. Died 1671 , aged 70.

${ }^{44}$ The Sermons. . . (1656) 93.
} 
believers succumb to their infirmities, they can rely on God's covenanted promise of mercy. He puts the point vividly:

What man will cut off his Nose, because there is filth in it?. . What Father wil knock his Child on the Head, because a wart grows on its Forehead. These infirmities in the Saints and People of God are their warts...45

It now becomes clear that in analysing Puritan thinking about Union with Christ, we need to take account of the way in which they use one model to supplement another. Covenant Theology provided them with a contractual model. But at the same time they fused it with another model. William Bridge has introduced us to that by speaking of a 'conjugal relationship'.

\section{Spiritual Marriage}

On 18 November 1693, Thomas Doolittle, who died in 1707, wrote a personal covenant which illustrates in a moving way what the Covenant of Grace meant in the spiritual life of the period. Amongst much else, he wrote, addressing God, that, since God has offered Jesus Christ

... to be my head and husband, and callest me to be espoused to him, I do solemnly here join my self in marriage-covenant to him, that he may be mine, and I may be his... I do here, with willingness of heart. . . sincerely, and gladly take thee for my Lord, Head and Husband, to love honour and obey thee, whether I shall be rich or poor, in sickness or in health, in a better or worse condition in this world, till death shall separate my soul from my body, for thee to be mine also after death, knowing that death shall not separate thee and $\mathrm{me}^{46}$

This remarkable rephrasing of the familiar words of the Marriage Service is a fitting introduction to the way in which union with Christ was conceived as a spiritual marriage.

Nowadays we are, most of us, quite unfamiliar with formal marriage contracts but they were a social reality in the seventeenth century. Nevertheless, what is surprising is the

\footnotetext{
45Ibid., 394-5.

${ }^{46}$ From the unpaged 'Memoir' prefixed to A Complete Body of Practical Divinity (London 1723). For Doolittle (1632?-1707) of Pembroke College, Cambridge; ejected from Rectory of St Alphage, London Wall, 1662; maintained a Dissenting academy, v., CR., DNB.
} 
ease with which the language of the later romantic conception of marriage trips off the tongues of Puritans when speaking of union with Christ. There was no more dynamic expression of the inner meaning of this experience than that which exploited the language of wooing, espousal, courtship and marriage, and it was by no means confined to those who are usually credited with leanings towards mysticism.

Richard Sibbes (1577-1635) was one of the most influential of Puritan preachers, both from the pulpit of Trinity Church, Cambridge, and after 1618 at Gray's Inn, London. He it was who said, 'To preach is to woo'. He explained this statement by adding,

The preachers are 'paranymphi', the friends of the bridegroom, that are to procure the marriage between Christ and his Church; therefore, they are not only to lay open the riches of her husband, Christ, but likewise to entreat for a marriage, and to use all the gifts and parts that God hath given them to bring Christ and his Church together. ${ }^{47}$

Both John Flavel (d.1691) and Thomas Goodwin (1600-1680) made use of the analogy of courtship between a king and a pauper in this context, albeit in a slightly different way from each other. Said Goodwin '... .we are no more able to woo Jesus Christ than the meanest country creature, one that walks up and down the streets in all rags and poverty, is able to woo a King.' Then comes a rather quaint touch-but the Father comes and teaches us to woo Jesus Christ, and makes representations of Christ to us' and he concludes 'this wooing work' belongs to the Father. ${ }^{48}$ Flavel's picture reverses the roles of the participants.

A king from heaven makes suit for a poor sinner's heart, woos for union with sinful creatures, rejoices exceedingly, when he wins their consent, and espouses them for ever to himself, when he obtains it...

And the wooing culminates in an 'honourable mystical union'.49 Walter Cradock echoes Sibbes's comparison of preaching with wooing when he says that Jesus Christ,

${ }^{47}$ Works V, 505-6. For further comment, v., Peter Lewis, The Genius of Puritanism (1979) 51.

${ }^{48}$ The Object and Acts of Justifying Faith in Works VIII, 158, 155.

${ }^{49} A$ Coronation-Sermon in Works (London 1820) VI, 554, 557. 
sends us not to hire servants. . We are not sent to get Gally-slaves to the Oares, or a Beare to the Stake: but he sends us to wooe you as spouses, to marrie you to Christ: and in wooing there must not be harsh dealing: and when a man hath wooed and got a wife she must be kindly used... 50

This reveals the appealing and tender aspect of Puritan preaching. As Thomas Shepherd of New England put it, 'Whatever the secret purpose of Christ is, I regard not; In this Evangelical dispensation, he makes love to all'.51

Whom precisely does Christ marry, the individual or the Church? For Thomas Goodwin, 'every soul is a daughter of God"52 and is the object of Christ's courting. James Baillie, on the other hand, writes of a 'most strait union betweene Christ and his Church' in the spiritual marriage. ${ }^{53}$ The distinction is not without its significance but most writers oscillate freely between the two. Perhaps most would agree with Thomas Shepherd in his exposition of the parable of the Ten Virgins: by Virgins are meant whole particular Churches of Christ, together with the several Members thereof' ${ }^{54}$ John Owen also agrees. He can write that Christ loves the soul 'and the soul having given itself unto Christ, loveth him also'. ${ }^{55}$ But that does not preclude the corporate emphasis. The Church is married unto her Maker, and her Redeemer is her husband' ${ }^{56}$

When the Puritans describe their relationship with Jesus Christ in terms of spiritual marriage, they guide us into the inner sanctum of their piety. Even Dr John Owen, whose passion for minute logical distinctions so frequently makes his literary style turgid, becomes eloquent, even lyrical, when he pursues this theme. Christ and believer give themselves to each other in the spiritual marriage and this, he says, is,

${ }^{50}$ Gospel-Libertie (1648) 28.

${ }^{51}$ The Parable of the 10 Virgins (1640) 23.

${ }^{52}$ The Object and Acts of Justifying Faith in Works VIII, 155.

${ }^{53}$ Spiritual Marriage: Or, The Vnion betweene Christ and his Chorch. As it was delivered in a Sermon at Westminster, the First of Ianvarie, Anno Dom. 1626 (London 1627).

${ }^{54}$ The Parable of the 10 Virgins, 11.

${ }^{55}$ Of Communion with God, Father, Son and Holy Ghost in Works II, 118.

${ }^{56}$ Ibid., 54. 
... a making over of their persons one to another. . .Christ makes himself over to the soul, to be his, as to all the love, care, and tenderness of a husband; and the soul gives itself wholly unto the Lord Christ, to be his, as to all loving, tender obedience. . . 57

And just as the husband bestows gifts upon his wife so

Christ gives himself to the soul, with all his excellencies, righteousness, preciousness, graces, and eminencies, to be its Saviour, head, and husband, for ever to dwell with it in this holy relation. 58

There is no evading the highly personal nature of the relationship. Thomas Goodwin had sharp words on this point. God does not love people because they fulfil certain duties or approve of certain dogmas or respect certain rules. On the contrary,

God in his love pitcheth upon persons. . .God doth not pitch upon propositions only; as to say, I will love him who believeth, and save him, as those of the Arminian opinion hold; no he pitcheth upon persons. And Christ died not for propositions only, but for persons. ${ }^{59}$

Naturally, the Puritans had a number of Biblical texts at their disposal to help them elaborate their teaching about the spiritual marriage, but one had a strong influence on their vocabulary. That was the Song of Songs. It is odd that Max Weber should have written that this book 'was for the most part simply ignored by the Puritans'.60 This is not so. G. Nuttall has drawn attention to the substantial number of books by Puritans dealing with the Song of Songs, from George Gifford's Fifteen Sermons on the Song of Songs in 1610 to James Durham's, Clavis Cantici: or an Exposition of the Song of Solomon in 1668.61 And in addition there are large numbers of incidental references. It is safe to say that the Song of Songs made a considerable impact on the thinking of the Puritans.

${ }^{57}$ Works II, 56.

${ }^{58}$ Ibid.

${ }^{59}$ Ephesians in Works II, 15.

${ }^{60}$ The Protestant Ethic and the Spirit of Capitalism (trans. Talbot Parsons, 1948) 238, n. 97.

${ }^{61}$ G.F. Nuttall, 'Puritan and Quaker Mysticism' in Theology (1975) 521-5. Jerald C.Brauer makes the same point in 'Types of Puritan Piety', Church History 56 (1987) 48-9. 
Some writers were particularly attracted to the book, giving the concept of spiritual marriage a large place in their thinking. Three examples may be noted. Francis Rous (15791659), a Cornishman and a lay theologian was at various times in his career Provost of Eton, a lay assessor in the Westminster Assembly and the Speaker of the Nominated Parliament. His substantial volume, The Mysticall Marriage (1635), as its title suggests, was devoted to this theme. Edward Polhill (162294?) was also a lay theologian and lived at Burwash in Sussex and gives close attention to this theme, amongst others, in his book Christus in Corde(1680). Samuel Rutherford (1600?-1661) was a prominent Presbyterian leader in Scotland. Stickler for Calvinism as he was, he could hardly contain himself in his letters when he came to mention Jesus Christ. All three of them made the fullest use of the metaphor of marriage.

'Come therefore into me, oh thou that art love, and love thyself into me', exclaimed Rous. ${ }^{62}$ Of the saints, Polhill writes that Christ 'himself is the great center of their love; He is ravished, nay, excordiated with their single eye of faith and chain of obedience, Cant. 4.9. they are ravished in him who is totus desideria. . .63 And Rutherford also expresses his yearning for Christ:

we cannot rest till we be in other's arms-and o, how sweet is a fresh kiss from his holy mouth: His breathing that goeth before a kiss upon my poor soul, is sweet, and hath no fault, but that it is too short. ${ }^{64}$

In fact, Rutherford has an obsession for words like 'kiss' and 'kissing'. The twentieth century reader may well find the sexual undertones of this language distasteful. Modern Biblical scholarship has made it extremely difficult for us to read the Song of Songs as an analogy of the relationship between Christ and the Church, although for centuries that was the only orthodox way to interpret it. And there is the added difficulty that Freud may have robbed us of our sexual innocence. Any modern sexual embarrassment would not be shared by our authors. There was more to these authors than revelling in an erotic mysticism. G. Nuttall has emphasised the essential

${ }^{62}$ The Mysticall Marriage, 323.

${ }^{63}$ Quoted by G.F.Nuttall, op. cit., 523.

${ }^{64}$ Charles Thomson, The Letters and Life of. . .Samuel Rutherford, I, 324. 
soberness of Polhill's language and his ethical concern ${ }^{65}$ and Gordon Wakefield similarly has drawn attention to the same interest in morality in Francis Rous. ${ }^{66}$ Jerald Brauer's recent study of Rous, ${ }^{67}$ agrees while insisting, in opposition to Wakefield, that Rous was a genuine mystic. But even so, he adds, 'within Puritanism he appears as a moderate'. ${ }^{68}$ To us his erotic language may sound excessive, but not so when compared with some of his contemporaries.

Even writers who are not usually considered to have mystical elements in their work are happy to use the erotic language of the Bible on occasion. Thus, Thomas Goodwin,

Cant.1.2. Let him kiss me with the kisses of his mouth, for thy love is better than wine.' And behold how Christ dismisseth his spouse filled with himself, and full of joy; for what virtue and efficacy must there be in the kisses of his mouth, whose lips breathe life, Gen ii.7. . .69

\section{Indwelling}

If the idea of covenant provided the Puritans with the objective framework for their teaching about union with Christ, and the concept of marriage gave them a means for expressing its emotional intensity, the analogy of indwelling confronted them with a difficult challenge to reconcile the objective and subjective elements in the teaching.

It is an ancient theological principle that the Persons of the Holy Trinity do not act in isolation from one another. The mainline Puritans consequently taught that the most significant work in salvation was done by the Trinity. As Thomas Goodwin put it, 'there is more done for us in heaven than is done in our hearts' at the time of conversion. ${ }^{70}$ It was also assumed that conversion involved divine activity within the human personality. It involves indwelling.

\footnotetext{
${ }^{65}$ 'Puritan and Quaker Mysticism', 323, 324.

${ }^{66}$ Puritan Devotion, 105.

${ }^{67}$ Francis Rous, Puritan Mystic, 1579-1659: An Introduction to the Study of the Mystical Element in Puritanism (PhD University of Chicago).

68'Types of Puritan Piety', 155.

${ }^{69}$ Of the Objects and Acts of Justifying Faith in Works VIII, 401.

${ }^{70}$ Ibid., 144.
} 
John Owen, for example, insisted that it does mean, first of all, the indwelling of the Holy Spirit. ${ }^{71}$ He took issue with those who denied a personal indwelling. He stated categorically, "To say the Spirit dwells in us, but not the person of the Spirit, is not to distinguish de modo, but to deny the thing itself' ${ }^{72}$ At the same time, the Spirit does not assume our nature and so make us 'one person with him, but dwells in our persons, keeping his own and leaving our personality infinitely distinct'. It is this personal indwelling, he maintained, which secures for us the greatest of all his graces, union with Jesus Christ. ${ }^{73}$ Stephen Charnock agreed and he, like so many Puritan authors, insists that it is the indwelling of the Holy Spirit in both Jesus Christ and in the believer which makes union between them possible. ${ }^{74}$

Is this indwelling confined to the Holy Spirit? Not at all, says John Howe. He argues that there is an indwelling of the Trinity in the believer. His argument is quite simple: Wheresoever one hypostasis. . .is present, there the whole Trinity is present'. ${ }^{75}$ This assertion agrees with that of a more radical Puritan than Howe, Morgan Llwyd, the Puritan minister of Wrexham:

One holy Scripture says that the Father is in us; and another the Son; and a third that the Holy Spirit is in every pure, enlightened and humble heart. And all Scriptures together show (and I dare to say it) that the Holy Trinity is in us. ${ }^{76}$

There were Puritans, more radical than Morgan Llwyd, who made much of the divine indwelling and were not averse to positing some kind of merging of the human into the divine. But those who clung to Calvinistic orthodoxy were extremely nervous that too much emphasis on the indwelling, or at least

\footnotetext{
${ }^{71}$ He devotes chapter VIII of The Doctrine of the Saints Perseverance (1654) to a detailed exposition of the thesis.

${ }^{72}$ Works XI, 333.

${ }^{73}$ Ibid., 336.

${ }^{74}$ Works (London 1684) II, 31.

${ }^{75}$ The Living Temple in Works III (1870) 446-7.

${ }^{76}$ Llyfr y Tri Aderyn in (ed. T.E.Ellis), Gweithiau Morgan Llwyd o Wynedd (Bangor 1899) I, 187. For Llwyd (1619-59) v., G.F.Nuttall, The Welsh Saints (1957) 37-54; M.Wynn Thomas, Morgan Llwyd (Writers of Wales Series, Cardiff 1974); E.Lewis Evans, Morgan Llwyd (Liverpool 1930); DNB.; Dictionary of Welsh Biography.
} 
the misinterpretation of it, would compromise the infinite gulf between the Creator and the creature.

What then of the indwelling of Christ? Is He present in the human personality in a personal way? Thomas Goodwin replied, 'Yes!' without hesitation. The Covenant of Grace, he argued, is a covenant of persons, 'and God gives the person of Christ to us, and the person of the Holy Ghost to us' ${ }^{77}$ And yet elsewhere he appears to be somewhat hesitant: 'I answer, according to the light I have-and I humbly submit what I have to say-Christ himself dwells in you immediately by himself'. He goes on to say that he is opposed to those who say that Christ 'dwells in us only by his Spirit' and still more so those who say that 'both Christ's and the Spirit's dwelling in us is but the graces they work in us ${ }^{\prime 78}$ We may assume that John Bunyan agreed with Goodwin when he portrays Emmanuel taking up residence in Mansoul in The Holy War.

But if it is said that Union with Christ means that $\mathrm{He}$ personally dwells in believers, is it something similar to Incarnation? John Owen, like other Puritans, was concerned to make it quite clear that this was not so. He said, 'Personal, or hypostatical union, is that of different natures in the same person, giving them the same singular subsistence. This none pretend to with Jesus Christ'. His suggestion is that the union of believers with the Person of Christ, 'is spiritual and mystical, whereby they are in him and he in them' ${ }^{79}$ And he insists elsewhere that Christ does not assume our nature in the way that he assumed flesh in the incarnation. Rather He dwells in our persons in such a way that his personality and ours are 'infinitely distinct'. It is a 'spiritual union' ${ }^{80}$ What does this amount to? Is he saying anything more than that the union is unique and ultimately not only mystical but mysterious?

It is striking that Samuel Annesley was prepared to go further. He admits that Union with Christ does much resemble the union of the two natures in Christ', although there are more differences than similarities. But he does go as far as

77 Works II, 151.

${ }^{78}$ Ibid., II, 393.

${ }^{79}$ Ibid., II, 313.

${ }^{80}$ Ibid., XI, 336. 
to say that the believing soul 'hath no kind of denomination, but what it hath from its union with Christ' ${ }^{81}$ Its essential being is grounded in the union.

It must be admitted orthodox Puritans like Owen, Goodwin, Howe and Annesley, seem to have had difficulty explaining lucidly precisely what indwelling meant.

\section{Communion}

It might prove difficult to provide a satisfactory analysis of the indwelling of Christ in believers, but the Puritans had no doubt at all about its reality. They had much to say about the communion that stemmed from it-communion with God and with other Christians.

To reiterate a point that has already been made it means that the believer is in receipt of all God's gifts, for our communion with God is only through the Mediator, Jesus Christ. As Matthew Barker put it, 'All Gods approaches to us are. . .through him; All that Light, Life, and Love: which God communicates to his people, is through him alone. ${ }^{82}$ This involves the presupposition that we are united with the whole Christ, as Barker goes on to explain. Jesus Christ 'assumed our Nature into Union and Communion with God'; by his life and teaching 'he did guide and lead men in their right way to Fellowship with his Father'; by his death he secured reconciliation between us and God; by his Resurrection 'Believers came to be raised to newness of Life'; by his Ascension He ensured that 'Divine influence and Power descends' whereby believers 'are carryd up above the World, and ascend up to Heaven'; and, finally, by his Intercession he pleads 'that his People might have Union and Communion with God'. ${ }^{83}$ So our present union with Christ does not in any way mean that we can ignore the earthly ministry of the 'Jesus of History'.

John Owen analysed the experience in his treatise, Of Communion with God the Father, Son, and Holy Ghost (1657). ${ }^{84}$

\footnotetext{
${ }^{81}$ Supplement to the Morning-Exercise (1674) 36.

${ }^{82} \mathrm{~A}$ Continuation of Morning-Exercise (1683) Sermon xix, 1022.

${ }^{83}$ Ibid., 1025.

${ }^{84}$ In Works (1862) II, 1-274. Sinclair B. Ferguson presents an excellent summary of it in John Owen on the Christian Life (Banner of Truth 1987) 74-98.
} 
'Communion', he defines as 'the mutual communication of such good things as wherein the persons holding that communion are delighted, bottomed upon some union between them' ${ }^{85}$ As Sinclair B. Ferguson rightly says, for Owen 'communion' includes 'Both the union with Christ which gives the Christian his status before God, and the communion with God which is the fruit of that status' ${ }^{86}$

Owen believed that it is possible to distinguish between the forms of communion enjoyed by a believer with each of the Persons of the Trinity, although their operations are intertwined. Our communion with the Father is characterised by love. Through Jesus Christ we recognise this love as the love of the Father and that kindles a reciprocating love in the believer's heart. ${ }^{87}$

Our communion with the Holy Spirit makes us appreciate that his most significant work is securing 'spiritual union. . .with the Lord Jesus Christ' ${ }^{88}$ In 'the first bestowing of the Spirit, we have union with Christ' and at the same time that is also the beginning of our spiritual quickening. ${ }^{89}$ There is an intellectual consequence, for the Spirit implants 'a saving light in the mind' so that the believer is disposed to embrace God's truth. ${ }^{90}$ The Spirit inhabits the believer, glorifies Christ ${ }^{91}$ and transforms us into adopted children of God.92

It follows that union with Christ is central to the believer's spiritual life and ultimate salvation. In expounding the character of the communion with Jesus Christ that follows, Owen makes much of the conjugal nature of the union and relies on the Song of Songs for his illustrations. Nothing is more precious to the Christian than the fact that, thanks to his sacrificial death, Christ is endowed with all grace and bestows it lavishly upon the believer. 'All our reliefs are thus in our

\footnotetext{
${ }^{85}$ Works II, 8.

${ }^{86} \mathrm{Op}$. cit., 75.

${ }^{87}$ Works II, 22, 24.

${ }^{88}$ Ibid., XI, 336.

${ }^{89}$ Ibid., 337.

${ }^{90}$ Ibid., 345.

${ }^{91}$ Ibid., II, 238.

92Ibid., 241.
} 
Beloved. Here is the life of our souls, the joy of our hearts, our relief against sin and deliverance from the wrath to come. ${ }^{93}$

One very comforting thought that stemmed from this aspect of their teaching about union with Christ was a doctrine of substitution. Perhaps David Clarkson expressed it as well as anyone when he wrote, 'His riches is ours, and our poverty his. . .His righteousness is ours, and our sins are his. . .His glory is ours, and our shame is his... ${ }^{94}$

But all was not triumphalism. Many of these authors suffered harassment and oppression, and some of them outright persecution. And in addition we need to recall that pain and ill health were chronic features of seventeenth century life. Nothing is more moving in Puritan literature than the way in which people felt that suffering brought them nearer to Jesus Christ. Jeremiah Burroughs expressed this experience in a telling way, when he asserted that God's intention in the eternal election was to make us, 'conformable to [his] Son: And he would have all the members of his Son, to be conformable to him in his sufferings. ${ }^{195}$ It is this conviction that Walter Cradock expressed succinctly in one sentence, 'All a Christian's life is spent either in believing, or in doing, or in suffering. ${ }^{96}$ The concern of the ascended Christ for sinners is tenderly expressed by Thomas Goodwin in that remarkable document, The Heart of Christ in Heaven Towards Sinners on Earth (1642). It is a delicate and touching exercise in exploring the passibility of the God-Man's ascended human nature while respecting the classical doctrine of the impassibility of his divine nature. It was this belief that suffering was an aspect of the Christian's union with Christ that sustained so many people in that age. Thus, Samuel Rutherford during his period as a prisoner in Aberdeen from 1636 to 1638 was able to give enthusiastic expression to his conviction that it was a great privilege to suffer,

He hath made all his promises good to me. . .I would not exchange my bonds with the plastered joy of this whole world. It hath pleased him to make a sinner, the like of me, an ordinary banqueter in his house-

\footnotetext{
${ }^{93}$ Ibid., 68-9.

${ }^{94}$ The Practical Works III, 167.

${ }^{95}$ The Saints Happinesse (1660) 529-30.

${ }^{96}$ Gospel-Holinesse (1651) 363.
} 
of-wine, with that royal princely One, Christ Jesus. . .How sweet must he be, when that black and burdensome tree, his own cross, is so perfumed with joy and gladness! ${ }^{97}$

\section{In Conclusion}

This essay has but a modest aim. It has concentrated on those Puritan theologians who adhered to orthodox Calvinism. It has presented evidence to suggest that both the experience and the doctrine of union with Christ was fundamental to their Christianity. Those more radical Puritans such as the Quakers, Morgan Llwyd, William Dell, William Erbury and others like them have not been considered here. It may well be, however, that sufficient has been said to suggest that their more orthodox fellow-Puritans had sought to accommodate their interest in subjectivity. That they sought to do it in the context of a powerful Christological emphasis. Moreover, since they placed union with Christ at the very commencement of the Christian's life as a Christian, a fuller treatment of the theme would require close study of its implications for sanctification, morality, eschatology, ecclesiology and the life eternal.

${ }^{97}$ Letters I, 222. 